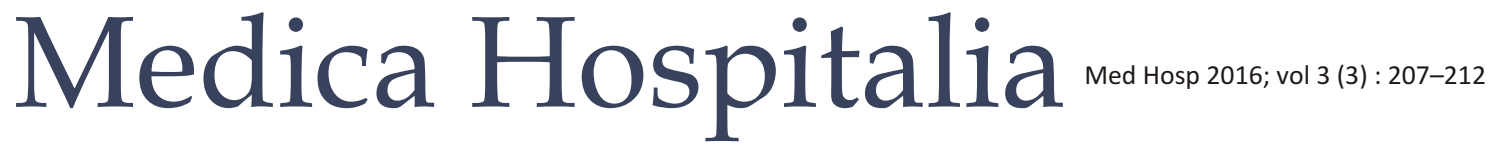

Clinical Practices

\section{Modifikasi Tekstur Makanan dan Minuman Pasien Disfagia}

\author{
Niken Puruhita, Rani Armeidani, Ayu Kusumadewi \\ Bagian/KSM Gizi Klinik Fakultas Kedokteran Universitas Diponegoro/RSUP Dr. Kariadi Semarang
}

\begin{abstract}
Abstrak
Disfagia adalah terhambatnya proses perpindahan makanan dan cairan dari mulut ke lambung. Komplikasi disfagia antara lain malnutrisi, dehidrasi, pneumonia aspirasi dan bahkan kematian. Pasien disfagia biasanya mengalami kesulitan mengkonsumsi makanan reguler dengan konsistensi bervariasi. Perubahan tekstur makanan yang sesuai dapat menurunkan risiko pneumonia aspirasi, meningkatkan asupan dan status gizi pasien disfagia. Modifikasi tekstur makanan secara bertahap disesuaikan dengan perkembangan kondisi pasien. Kemampuan menelan pasien diuji berkala sebelum diberikan makanan yang lebih padat konsistensinya. Modifikasi tekstur makanan hendaknya dilakukan tanpa mengubah warna dan cita rasa untuk meningkatkan selera makan pasien. Bentuk dan tekstur makanan yang tersedia di RSUP Dr. Kariadi meliputi makanan biasa, makanan lunak, makanan saring, dan makanan blenderized. Minuman encer berisiko menyebabkan aspirasi pada pasien disfagia. Modifikasi minuman dengan menambahkan pengental akan lebih mudah ditoleransi. Pengental minuman ini belum tersedia di Indonesia, sehingga RSUP Dr Kariadi menggunakan jeli sebagai pengental. Metode yang banyak dipakai untuk mengukur kosistensi makanan untuk pasien disfagia antara lain adalah line spread test dan fork test.
\end{abstract}

Kata kunci : disfagia, tekstur, pengental

\section{Texture Modified Foods and Liquids for Dysphagic Patients}

\begin{abstract}
Dysphagia is difficulty in the passage of swallowed food and liquid from the mouth to the stomach. Complications of dysphagia include malnutrition, dehydration, aspiration pneumonia, and even death. Dysphagic patients usually have difficulty eating regular meals with varying consistency. Appropriate texture modified food can reduce the risk of aspiration pneumonia, increasing intake and nutritional status of dysphagic patients. Texture food modification is gradually adjusted to the development of the patient's condition. The ability of patients to swallow should be regularly tested before higher food consistency is given. Texture modification should be done without changing the color and flavor of food to enhance the patient's appetite. The texture modified foods available at the Hospital Dr. Kariadi include regular diets, soft foods, pureed foods, and blenderized foods. Clear liquids can risk of causing aspiration in dysphagia patients. Thickened liquid will be more easily tolerated. Thickener is not yet available in Indonesia, therefore, Dr Kariadi hospital has been using jellies as a thickener. The methods which are widely used to measure food consistency for dysphagi patients are line spread test and fork test.
\end{abstract}

Key words : dysphagia, texture, thickener

\section{PENDAHULUAN}

Disfagia adalah kesulitan menelan atau terhambatnya proses perpindahan makanan dan cairan dari mulut ke lambung. ${ }^{1}$ Disfagia dapat terjadi pada fase menelan orofaringeal dan esofageal. ${ }^{2}$ Disfagia dapat menyebabkan malnutrisi, dehidrasi, pneumonia aspirasi dan bahkan kematian. ${ }^{3}$ Malnutrisi pada pasien disfagia disebabkan oleh karena menurunnya asupan makanan, akibat penyakit yang mendasari terjadinya disfagia (seperti stroke, demensia, kanker kepala leher), efek samping terapi, dan penyakit neurodegeneratif lainnya. ${ }^{4}$ Prevalensi malnutrisi pada pasien disfagia berkisar antara 30,6\% sampai dengan 69,5\%.5,6 Kondisi kelemahan otot (terutama otot yang membantu proses menelan) terjadi pada pasien malnutrisi. Hal ini akan memperberat disfagia, menyebabkan asupan semakin berkurang, dan memperburuk status gizi. ${ }^{7}$

Modifikasi tekstur makanan dan minuman sangat penting dan paling sering dilakukan untuk terapi gizi pasien dengan disfagia. Makanan yang terlalu keras, menghasilkan remah-remah, dan cairan yang encer 
seperti air, jus buah maupun kopi dapat menyebabkan aspirasi pada sebagian besar pasien. Hal ini terjadi terutama pada pasien dengan gangguan motorik yang tidak dapat menahan cairan di mulut, pasien dengan respon faringeal yang lambat/ireguler, dan pasien dengan gangguan jalan nafas. Perubahan tekstur makanan diharapkan dapat menurunkan risiko pneumonia aspirasi, meningkatkan asupan dan status gizi pasien disfagia. ${ }^{3}$ Tulisan ini membahas modifikasi tekstur makanan dan minuman pasien disfagia neurogenik, dimana tidak terjadi obstruksi atau penyempitan sepanjang orofaring dan esofagus.

\section{Modifikasi tekstur makanan}

Pasien disfagia biasanya mengalami kesulitan mengkonsumsi makanan reguler dengan konsistensi bervariasi. Modifikasi bentuk makanan diperlukan untuk mempermudah proses menelan. Pasien dengan penurunan kesadaran pada umumnya memerlukan diet cair yang diberikan melalui pipa makanan (selang nasogaster) untuk menghindari aspirasi. Pasien dengan kesadaran baik dan kemampuan mengunyah tidak terganggu dapat diberikan diet setengah padat (semi solid). Diet semi solid ini diberikan dengan edukasi

\section{TABDE 1 \\ Jenis diet disfagia berdasar perubahan tekstur ${ }^{8}$}

Tahap
Deskripsi

\section{Contoh makanan yang direkomendasikan}

Level 1:

Dysphagia pureed

Level 2:

Dysphagia

mechanically altered

Level 3:

Dysphagia advanced

Level 4:

Reguler
Homogen, menyatu, konsistensi seperti puding. Tidak perlu mengunyah, hanya mengendalikan bolus saat proses menelan

Lembut, lunak, menyatu. Memerlukan fungsi mengunyah minimal

Setengah padat, lembut

Tidak ada modifikasi
Kentang tumbuk atau puding, daging dan sayur blender, yogurt

Buah kaleng/buah disetup, pasta, daging giling

Sereal lembut, nasi, kentang rebus potong dadu, daging iris tipis/cacah, telur

Tidak ada restriksi

\section{TABEL 2}

\section{Progresifitas jenis diet disfagia ${ }^{10}$}

\section{No. Jenis Diet}

Jenis makanan

\section{Test food}

Makanan padat pada umumnya

Semua makanan dipotong dadu, lembut. Tidak ada makanan yang keras dan berserat panjang

Semua makanan dicacah, tidak ada makanan yang keras atau membentuk remahan

Semua makanan dicacah, tidak ada makanan yang keras atau membentuk remahan

Semua makanan dibentuk puree
Makanan cair melalui selang makanan
Daging dipotong dadu

Daging cacah

Roti tawar

Buah yang lembut/ dibuat setup buah 


\section{TABEL 3}

\section{Bentuk dan tekstur makanan pada pasien dengan disfagia ${ }^{11}$}

\section{Tekstur Makanan}

Deskripsi

\section{Contoh Makanan}

Makanan cair

(Thin Puree)
Makanan cair dapat berupa susu, air kaldu, sirup, air madu, jus. Tekstur dari makanan ini halus dan lembut sehingga dapat diminum dengan menggunakan sedotan.
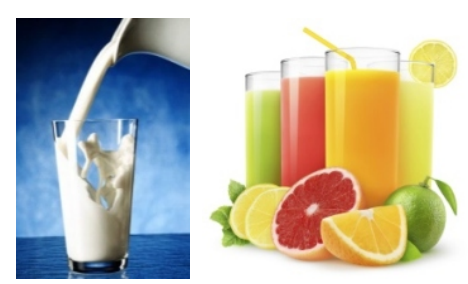

Makanan cair penuh/ kental (Thick Puree)
Makanan yang teksturnya lembut, berupa makanan saring atau blender yang disajikan diatas piring. Makanan disajikan dalam bentuk halus.
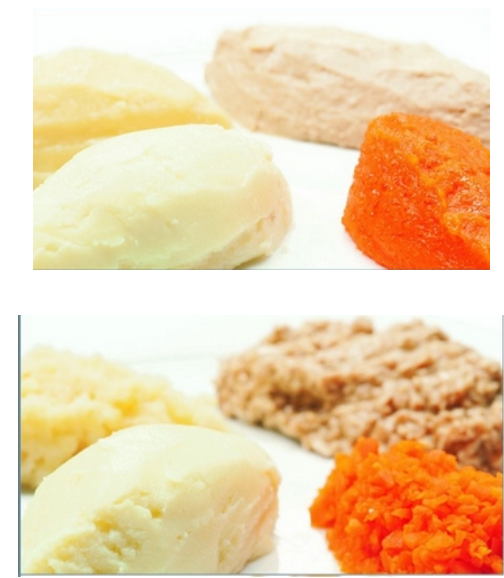

Makanan dengan tekstur yang lunak sedikit kasar. Saat mengkonsumsi makanan ini diperlukan sedikit kemampuan untuk mengunyah. Makanan ini dapat digunakan dalam proses belajar mengunyah pada pasien dengan disfagia.

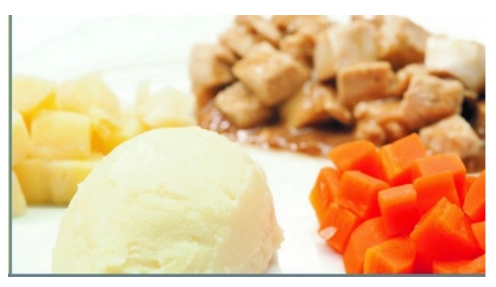

Makanan ini memiliki tekstur yang lunak, tandanya makanan ini dapat dihancurkan dengan garpu. Makanan ini dipotong berbentuk dadu, bukan makanan cincang. Makanan ini membutuhkan kemampuan untuk mengunyah.

Fork mashable

untuk mengunyah perlahan sampai makanan lumat dan tercampur dengan baik sebelum ditelan. Pasien dengan gangguan mengunyah dapat diberikan makanan yang sudah dimodifikasi teksturnya. ${ }^{8}$

Beberapa jenis makanan perlu dihindari untuk pasien disfagia seperti makanan berserat panjang (selada, nanas, seledri), makanan berkulit mudah lepas (kedelai, anggur), makanan dengan konsistensi campuran (sup sayuran dan daging, salad buah), makanan renyah (krupuk, roti panggang, pastry), makanan dengan remah-remah halus (biskuit), dan makanan yang keras (kacang, biji-bijian, jagung). ${ }^{9}$

Perubahan tekstur makanan secara bertahap disesuaikan dengan kondisi pasien. Menu dan bahan makanan sehari-hari yang dikonsumsi oleh keluarga dapat dimodifikasi bentuk dan teksturnya tanpa mengubah rasa agar dapat meningkatkan asupan pasien disfagia. Diet pada sebagian pasien disfagia dapat disesuaikan konsistensinya secara bertahap dengan mengacu tabel progresifitas diet (tabel 2). Tabel ini digunakan untuk menguji kemampuan menelan pasien sebelum diberikan makanan yang lebih padat konsistensinya. ${ }^{10}$

Perubahan tekstur makanan hendaknya dilakukan tanpa mengubah warna dan cita rasa. Penyajian sebaiknya dalam bentuk yang menarik untuk meningkatkan selera makan pasien. Contoh perubahan tekstur makanan yang disesuaikan dengan kemampuan pasien dalam mengunyah dan menelan makanan dapat dilihat pada tabel3. ${ }^{11}$

Jenis makanan yang disediakan di RSUP Dr. Kariadi juga disesuaikan dengan kemampuan pasien dalam mengunyah dan menelan makanan. Perubahan jenis makanan disesuaikan dengan perkembangan kondisi pasien. Bentuk dan tekstur makanan yang tersedia di RSUP Dr. Kariadi dapat dilihat sebagai berikut: 


\section{Makanan utama}

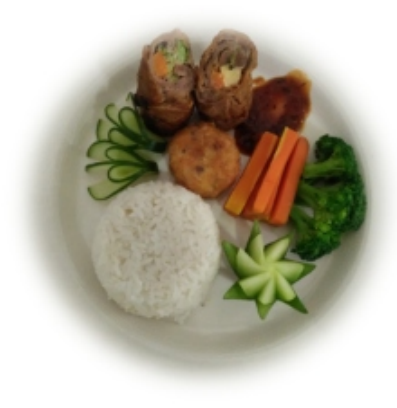

Makanan biasa

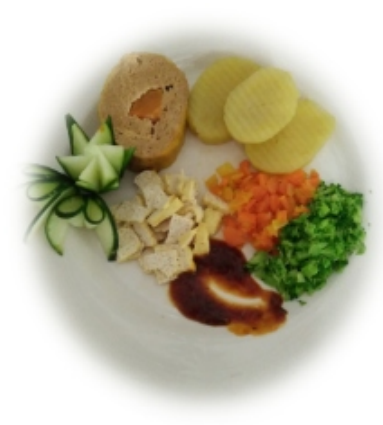

Makanan lunak

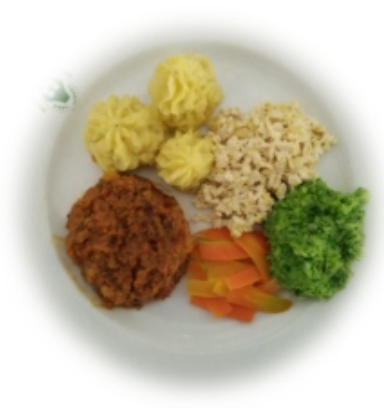

Makanan saring

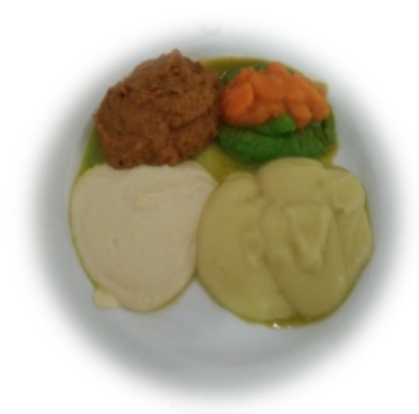

Makanan blenderized

Makanan snack

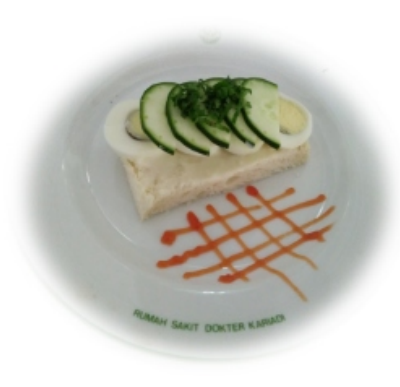

Makanan biasa

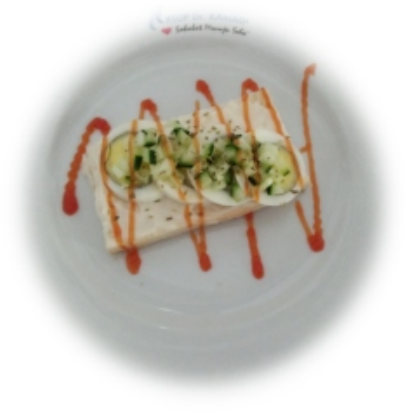

Makanan lunak

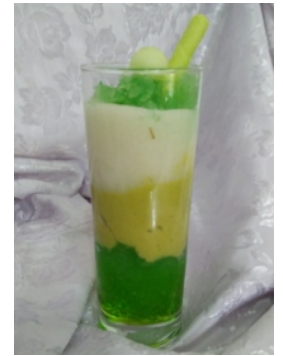

Makanan saring

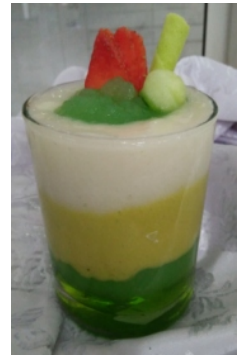

Makanan blenderized

\section{Modifikasi minuman pasien disfagia}

Minuman yang encer berisiko menyebabkan aspirasi pada penderita disfagia. Cairan yang lebih kental seperti madu lebih mudah ditoleransi oleh karena mengalir perlahan di orofaring. Cairan yang secara alamiah encer seperti air putih, jus, kopi dan teh dapat dimodifikasi kekentalannya dengan memberikan pengental. Penggunaan pengental (thickened) dianjurkan untuk minuman pasien disfagia. Cairan yang dikentalkan akan mengalir perlahan di mulut dan tenggorokan, sehingga memberikan waktu penderita disfagia untuk menelan dengan mudah dan aman. Penggunaan pengental cairan ini direkomendasikan untuk mempertahankan asupan cairan pasien disfagia. Pengental ini dapat dicampurkan pada minuman seperti air putih, teh, kopi, jus maupun kuah. Pengental bersifat mengentalkan cairan namun tidak merubah rasa. Beberapa pustaka melaporkan kualitas hidup pasien yang mengkonsumsi cairan dengan pengental ini lebih rendah, ${ }^{13-16}$ namun penelitian lain melaporkan pasien lebih memilih minum cairan yang dikentalkan daripada harus dipasang selang nasogaster. ${ }^{17}$

Pengental minuman ini belum tersedia di Indonesia, sehingga RSUP Dr. Kariadi menggunakan jeli sebagai pengental. Modifikasi jeli sebagai pengental di RSUP Dr. Kariadi adalah dengan menambahkan air pada saat membuat bahan pembuat jeli yang dijual di pasaran. Bahan pembuat jeli setengah bungkus akan dicairkan dengan air sebanyak 1500-1700 ml, sehingga kurang lebih menghasilkan 6-7 gelas berukuran $200 \mathrm{ml}$. Penggunaan modifikasi ini dilakukan pada pasien yang kesulitan mengkonsumsi air minum dengan tujuan untuk mengurangi risiko dehidrasi. Penambahan air yang digunakan disesuaikan juga dengan kemampuan pasien dalam menelan bentuk minuman yang dikentalkan.

\section{Metode pengukuran konsistensi diet disfagia}

Berbagai metode diperkenalkan untuk mengukur kosistensi makanan untuk pasien disfagia. Metode yang banyak dipakai antara lain adalah line spread test dan fork test. Metode line spread test diperkenalkan oleh Paik et al., yaitu menggunakan piring kaca dengan gambar lingkaran dengan jarak 0,5 cm. Tabung terbuka dengan 


\section{TABDL 4}

\section{Kategori konsistensi dengan fork test ${ }^{3}$}

Kategori

Deskripsi

Tingkat 1:

cair encer

Tingkat 2 :

seperti "nectar"

Tingkat 3 :

seperti madu

Tingkat 4 :

seperti puding
Jenis makanan yang semuanya segera mengalir dengan mudah dan tidak ada yang tertahan di atas garpu.

Jenis makanan yang mengalir perlahan diantara jeruji garpu dan hanya sedikit yang tertahan di atas garpu

Jenis makanan yang mengalir perlahan diantara jeruji garpu dan sebagian besar tertahan di atas garpu

Jenis makanan yang dapat diambil dengan garpu dan semua tertahan di atas garpu.
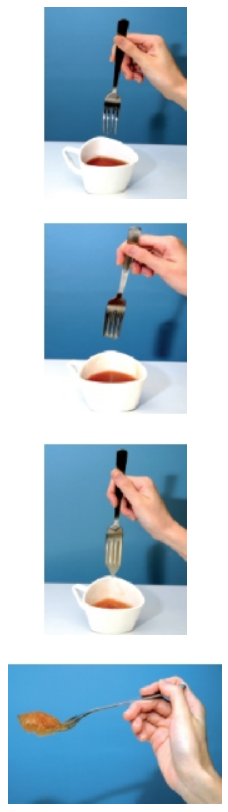

tinggi $2 \mathrm{~cm}$ dan diameter $2 \mathrm{~cm}$ diletakkan di tengah lingkaran dan diisi dengan $5 \mathrm{ml}$ sampel makanan bersuhu $37^{\circ} \mathrm{C}$. Tabung diangkat dan makanan di dalamnya dibiarkan mengalir selama 1 menit, jarak dari tengah lingkaran sampai ujung terjauh aliran makanan diukur. Makanan kemudian dikelompokkan menjadi 4 jenis, yaitu :1) > 4cm, 2) 3,0-3,9 cm,3) 1,1-2,9 cm dan 4) <1 $\mathrm{cm}$. Semakin jauh makanan mengalir dari pusat lingkaran berarti semakin encer konsistensinya. Metode ini mudah dilakukan, namun memerlukan alat khusus. ${ }^{18}$ Metode lain yang lebih sederhana adalah fork test. Metode ini berdasarkan aliran atau tetesan makanan antara jeruji garpu dan makanan yang tertinggal di garpu. Penelitian yang dilakukan Park et al. melaporkan validitas dan reliabilitas fork test yang cukup tinggi. Tabel 4 menunjukkan kategori konsistensi dengan menggunakan fork test. ${ }^{3}$

Fork test digunakan sebelum memberikan makanan/cairan kepada pasien disfagia. Makanan yang lebih encer berisiko menyebabkan pasien disfagia tersedak. Pemberian pengental dapat meningkatkan konsistensi. ${ }^{3}$

\section{SIMPULAN}

Terapi gizi pasien disfagia membutuhkan modifikasi tekstur makanan dan minuman, sehingga dapat menelan dengan mudah dan aman. Perubahan tekstur makanan dan minuman secara bertahap disesuaikan dengan perkembangan kondisi pasien dan kemampuan pasien dalam menelan. Diet yang sesuai dapat menurunkan risiko pneumonia aspirasi, mencegah dehidrasi, meningkatkan asupan, dan memperbaiki status gizi pasien disfagia.

Kerjasama, komunikasi, dan koordinasi yang baik antara dokter penanggung-jawab pasien, dokter spesialis gizi, ahli gizi, dan instalasi gizi diperlukan dalam pelayanan diet pasien disfagia yang optimal. Penelitian lebih lanjut diperlukan untuk mengevaluasi efektivitas, efisiensi, dan kendala yang timbul selama ini dalam pemberian modifikasi diet untuk pasien disfagia. Pengembangan strategi pelayanan gizi yang lebih baik diperlukan agar dapat memberikan diet yang sesuai dengan panduan tatalaksana diet pasien disfagia.

\section{DAFTAR PUSTAKA}

1. Berber O, Joshi JR. Dysphagia. Br J Hosp Med 2010;71(4 Suppl):M61-M63.

2. Schindler JS, Kelly JH. Swallowing disorders in the elderly. Laryngoscope 2002;112(4):589-602.

3. Park JW, Kim IJ, Lee HJ. Fork test: A new simple and reliable consistency measurement for the dysphagia diet. Geriatr Nurs 2016;37(4):292-5.

4. Wright L, Cotter D, Hickson M, Frost G. Comparison of energy and protein intakes of older people consuming a texture modified diet with a normal hospital diet. J Hum Nutr Diet 2005;18:213-9. 
5. Carrion S, Cabre M, Monteis R, Roca M, Palomera E, Serra-Prat $\mathrm{M}$, et al. Oropharyngeal dysphagia is a prevalent risk factor for malnutrition in a cohort of older patients admitted with an acute disease to a general hospital. Clin Nutr 2015;34(3):436-42.

6. Carrion S, Roca M, Costa A, Arreola V, Ortega O, Palomera E, et al. Nutritional status of older patients with oropharyngeal dysphagia in a chronic versus an acute clinical situation. Clin Nutr 2016;S0261-5614(16):30175-3.

7. Veldee MS, Peth LD. Can protein-calorie malnutrition cause dysphagia? Dysphagia 1992;7(2):86-101.

8. Groher ME, Crary MA. Dysphagia: Clinical management in adults and children. Maryland Heights, MO. Mosby. Elsevier: 2010. http://www.ncbi.nlm.nih.gov/pmc/articles / PMC3426263/table/t4-cia-7-287/

9. Irish Association of Speech and Language Therapists (IASLT) in association with Irish Nutrition and Dietetic Institute (INDI). Irish consistency descriptors for modified fluids and food consensus document. 2009.

10. Dysphagia diet advancement guidelines. Appendix C. 2015. Downloaded from http://policy.nshealth.ca/site_published/ DHA5/document_render.aspx?documentRender.IdType $=38$ \&documentRender.GenericField=1\&documentRender. $I d=531$ 91

11. National Patient Safety Agency (NPSA) Dysphagia Expert Reference Group in association with Cardiff and Vale University Health Board. Dysphagia diet food texture descriptors. 2011.
12. Germain I, Dufresne T, Ramaswamy HS. Rheological characterization of thickened beverages used in the treatment of dysphagia. J Food Eng 2006;73:64-74.

13. Macqueen C, Taubert S, Cotter D, Stevens S, Frost G. Which commercial thickening agent do patients prefer? Dysphagia 2003;18(1):46-52.

14. Pelletier CA, Lawless HT. Measuring taste acceptance in neurologically impaired adults. Food Qual Prefer 2003;14:595602.

15. Whelan K. Inadequate fluid intakes in dysphagic acute stroke. Clin Nutr 2001;20:423-8.

16. Goulding R, Bakheit AM. Evaluation of the benefits of monitoring fluid thickness in the dietary management of dysphagic stroke patients. Clin Rehabil 2000;14(2):119-24.

17. Hines S, McCrow J, Abbey J, Gledhill S. Thickened fluids for people with dementia in residential aged care fasilities: a comprehensive systematic review. JBI Library of Systematic Reviews 2009;7(16):761-824.

18. Paik NJ, Han TR, Park JW, Lee EK, Park MS, Hwang IK. Categorization of dysphagia diets with the line spread test. Arch Phys Med Rehabil. 2004;85(5):857-61. 